\title{
First record of Paratriacanthodes retrospinis Fowler, 1934 (Tetraodontiformes: Triacanthodidae) from India
}

\author{
Thayyil K. Sirajudheen and Appukuttannair Bijukumar* \\ 1 University of Kerala, Department of Aquatic Biology \& Fisheries, Kariavattom Campus, 695581, Thiruvananthapuram, Kerala, India \\ * Corresponding author. E-mail:abiju@rediffmail.com
}

\begin{abstract}
The Sawspine spikefish, Paratriacanthodes retrospinis Fowler, 1934, is reported from Indian waters for the first time, based on specimens collected from Sakthikulangara fishing harbor $\left(08^{\circ} 30^{\prime}\right.$ N, $76^{\circ} 53.3^{\prime}$ E), Kerala, southwest coast of India. Morphometric and meristic characters of the two specimens obtained correspond with those of P. retrospinis published previously.
\end{abstract}

Spikefishes (Tetraodontiformes: Triacanthodidae) inhabit waters below 50 meters and are distributed in the Atlantic, Indian, and western and central Pacific oceans (Tyler 1968; Matsura and Tyler 1998). Of the 23 species of spikefishes recorded, only two species, namely Macrorhamphosodes platycheilus Fowler, 1934 and Triacanthodes ethiops Alcock, 1894 have been recorded from the coasts of India (Kapoor et al. 2002; Froese and Pauly 2011). Paratriacanthodes Fowler, 1934 is one of the morphologically generalized genera of Triacanthodidae (Tyler 1980) and is mainly characterized by the presence of a pair of large ventral fin spines that can be erected ventro-laterally and locked in this position (Tyler 1962). Paratriacanthodes is represented by three species namely P. abei Tyler, 1997, P. herrei Myers, 1934, and Paratriacanthodes retrospinis Fowler, 1934 (Froese and Pauly 2011). This paper records P. retrospinis Fowler, 1934 for the first time from the Indian coast.

Two specimens were trawled off Kerala $\left(08^{\circ} 30^{\prime} \mathrm{N}\right.$, $76^{\circ} 53.3^{\prime} \mathrm{E}$ ), southwest coast of India at a depth of about 50 meters: ZSI/WGRC/IR/V 2083 (Western Ghats Regional Station of Zoological Survey of India, Calicut, Kerala, India), $34.8 \mathrm{~mm}$ SL, collected on 23 December 2009; AQB F S469 (Museum of Department of Aquatic Biology and Fisheries, University of Kerala, India), $36.5 \mathrm{~mm} \mathrm{SL}$, collected on 28 March 2011. Morphometric and meristic data were gathered following methods described by Strauss and Bond (1990).

The mainly diagnostic features are: dorsal fin VI+14-15; anal fin 13-14; pectoral fin 13; pelvic fin I+1. Body strongly compressed. Head small, conic, its length and width almost equal. Eyes large, $34 \%$ of head length, inter-orbital space concave and narrow. Mouth terminal with protrusible lower jaw and small conical teeth. Gill opening a small vertical slit in front of pectoral fin, not reaching lower margin of pectoral-fin base. Scales with rugged upright spinules in horizontal series on body and transverse series on lower half of head. Two dorsal fins; spinous first dorsal inserted over gill opening. Second dorsal and anal fins soft, without spines. First dorsal spine and pelvic spine with three rows of large antrorse spiny processes along their lengths, and hence the name retrospinis (Fowler 1934). Pelvic spine longer than first dorsal spine. Pale pink in color, with three lightly colored lines from lower jaw to anus, which disappears on preservation. Morphometric and meristic data are given in Table 1. The type specimen was described from the South China Sea by Fowler (1934) and reported subsequently from various countries bordering Indo-Pacific, including Hong Kong, Taiwan and Japan (Masuda et al. 1984), China, South Africa and Mozambique (Tyler 1986), New Caledonia (Matsuura and Tyler 1997) and Australia (Hutchins 2003). The record of this specimen from the southwest coast of India shows more extensive distribution of $P$. retrospinis in the Indian Ocean.

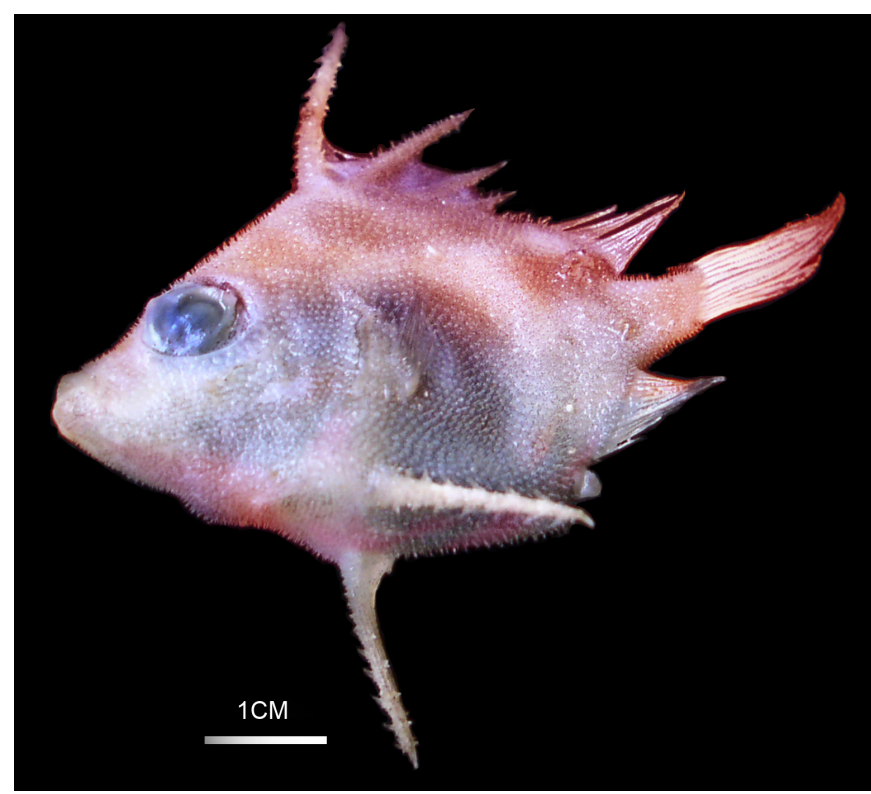

FIGURE 1. Paratriacanthodes retrospinis (ZSI/WGRC/IR/V/2083), 34.8 $\mathrm{mm}$ SL, collected from Sakthikulangara fishing harbour, Kerala, India. 
TABLE 1. Measurements and counts of Paratriacanthodes retrospinis collected from Kerala, India.

\begin{tabular}{|c|c|c|c|}
\hline CHARACTERS & ZSI/WGRC/IR/V/2083 & AQB F S469 & FOWLER (1934) \\
\hline Total length, TL (mm) & 45 & 46.5 & 114 \\
\hline Standard length, SL (mm) & 34.8 & 36.5 & - \\
\hline Weight (g) & 2.5 & 2.5 & - \\
\hline \multicolumn{4}{|l|}{ Measurements in \% SL } \\
\hline Body depth & 64.66 & 65.75 & - \\
\hline Head length & 46.26 & 46.58 & - \\
\hline Head depth & 43.10 & 44.66 & - \\
\hline Post-orbital length & 14.94 & 17.53 & - \\
\hline Eye diameter & 15.80 & 15.89 & - \\
\hline Pre-orbital length & 12.64 & 17.26 & - \\
\hline Pre-dorsal length & 52.01 & 55.34 & - \\
\hline Pre-pectoral length & 47.41 & 48.22 & - \\
\hline Pre-pelvic length & 51.72 & 57.53 & - \\
\hline Pre-anal length & 80.17 & 80.82 & - \\
\hline Caudal peduncle length & 9.77 & 12.88 & - \\
\hline Caudal peduncle depth & 9.20 & 9.59 & - \\
\hline Dorsal-fin length & 54.60 & 52.60 & - \\
\hline Anal-fin length & 12.93 & 14.79 & - \\
\hline Pectoral-fin length & 17.53 & 17.26 & - \\
\hline Pelvic-fin length & 34.20 & 38.90 & - \\
\hline Caudal-fin length & 28.74 & 27.95 & - \\
\hline First dorsal-fin spine length & 33.05 & 31.51 & - \\
\hline Pelvic-fin spine length & 37.07 & 38.90 & - \\
\hline Maxilla length & 6.32 & 6.58 & - \\
\hline Mandible length & 3.74 & 4.93 & - \\
\hline \multicolumn{4}{|l|}{ Counts } \\
\hline Dorsal-fin spines & 5 & 5 & 5 \\
\hline Dorsal-fin rays & 14 & 15 & 15 \\
\hline Pectoral-fin rays & 13 & 13 & - \\
\hline Anal-fin rays & 13 & 14 & 13 \\
\hline Pelvic-fin spines & 1 & 1 & - \\
\hline Pelvic-fin rays & 1 & 1 & - \\
\hline
\end{tabular}

ACKNOWLEDGMENTS: The authors thank Kerala State Council for Science Technology and Environment for the financial support for the current study.

\section{Literature Cited}

Fowler, H.W. 1934. Descriptions of new fishes obtained 1907 to 1910, chiefly in the Philippine Islands and adjacent seas. Proceedings of the Academy of Natural Sciences of Philadelphia 85: 233-367.

Froese, R. and D. Pauly. 2011. FishBase. Version 2010. Electronic Database accessible at http://www.fishbase.org. Captured on 13 August 2011.

Hutchins, J.B. 2003. Fishes checklist for Western Australia. http://www. museum.wa.gov.au. Captured on 07 November 2003.

Kapoor, D., R. Dayal and A.G. Ponniah. 2002. Fish Biodiversity of India. Lucknow: National Bureau of Fish Genetic Resources, 775 p.

Masuda, H., K. Amaoka, C. Araga, T. Uyeno and T. Yoshino. 1984. The Fishes of the Japanese Archipelago. Vol. 1. Tokyo: Tokai University Press, $437 \mathrm{p}$.

Matsura, K. and J.C. Tyler. 1997. Tetraodontiform fishes, mostly from deep waters, of New Caledonia; p. 173-208. In B. Séret (ed.). Résultats des Campagnes MUSORSTOM, Vol. 17. Memoirs du Museum National d'Histoire Naturelle 174: 1-213.
Matsura, K. and J.C. Tyler. 1998. Triacanthodidae; p. 227-228. In J.R. Paxton and W.N. Eschmeyer (ed.). Encyclopedia of Fishes. San Diego: Academic Press.

Strauss, R.E. and C.E. Bond. 1990. Taxonomic methods: morphology; p. 109-140. In P. Moyle and C. Schreck (ed.). Methods for Fish Biology. Bethesda: American Fisheries Society, Special Publication.

Tyler, J.C. 1962. The pelvis and pelvic fin of plectognath fishes: a study in reduction. Proceedings of the Academy of Natural Sciences of Philadelphia 114: 207-250.

Tyler, J.C. 1968. A monograph on plectognath fishes of the superfamily Triacanthoidea. Academy of Natural Sciences of Phildelphia16: $364 \mathrm{p}$.

Tyler, J.C. 1980. Osteology, phylogeny, and higher classification of the fishes of the order Plectognathi (Tetraodontiformes). National Oceanic and Atmospheric Administration, Technical Report. National Marine Fisheries Service, Circular 434: 422 p.

Tyler, J.C. 1986 Triacanthodidae; p. 887-890. In M.M. Smith and P.C. Heemstra (ed.) Smiths' Sea Fishes. Berlin: Springer-Verlag.

RECEIVED: September 2011

ACCEPTED: May 2012

Published OnLine: August 2012

EDITORIAL RESPONSIBILITY: Michael Maia Mincarone 